\title{
Recepcija Emmanuela Mouniera u Hrvatskoj i bivšoj Jugoslaviji do 1965. godine
}

\author{
Ivan Čulo* \\ institutfs@gmail.com
}

UDK: 1 Mounier, E.(497.1)“1945/1965“

141.82:23/28(497.1)

Izvorni znanstveni rad / Original scientific paper Primljeno: 15. prosinca 2016. Prihvaćeno: 22. siječnja 2017.

U radu se prikazuje i analizira recepcija francuskog katoličkog filozofa $i$ mislioca, pokretača personalističkog pokreta, Emmanuela Mouniera (1905-1950) u Hrvatskoj i bivšoj Jugoslaviji do 1965. godine. Prate se članci o Mounieru, o njegovu personalizmu i o njegovim djelima te o utjecaju nekih njegovih ideja. Na prve usputne odjeke njegove misli kod katoličkih i nekih drugih mislilaca u Hrvatskoj nailazimo već 30-ih godina, ali s njihove strane izostaje kako pozitivna, tako i negativna kritika. Ipak, Mounierova djelomična bliskost nekim idejama marksizma i socijalizma za njih nije bila prihvatljiva. I hrvatski mislioci u emigraciji zadržavaju taj rezervirani stav, dok je u zemlji nakon Drugoga svjetskog rata nastupilo doba u kojem je jedino javno prihvatljivo mišljenje bilo marksističko, a personalizam se kao »buržoaska «ilozofija odbacivao. Iznimka je donekle bio Mounier, prema kojemu poslijeratni marksisti imaju ambivalentan, a nakon raskola Tita i Staljina 1948. godine čak i prilično pozitivan stav. To je filozofsko-povijesni raritet, osobito kada se ima na umu da je Mounier bio izrazito katolički mislilac. Otuda recepciju Mouniera možemo gledati i kao prethodnicu tzv. približavanja kršćanstva i marksizma 60-ih godina prošloga stoljeća, ali i kao politički pragmatizam ondašnje jugoslavenske ideologije.

Ključne riječi: Emmanuel Mounier, personalizam, recepcija u Hrvatskoj i bivšoj Jugoslaviji, katolički mislioci, marksistički mislioci.

\footnotetext{
* Ivan Čulo, dipl. iur.; dipl. phil., doktorand na Fakultetu filozofije i religijskih znanosti Sveučilišta u Zagrebu; Institut Fontes Sapientiae, Kušlanova 59, HR-10000 Zagreb.
} 


\section{Uvodne napomene}

Emmanuel Mounier (Grenoble, 1. V. 1905. - Châtenay-Malabry, 22. III. 1950.) bio je, uz Jacquesa Maritaina i Nikolaja Berdjajeva, najvažniji predstavnik europskog personalizma, filozofskog pravca koji je u Francuskoj rezultirao i pokretom, kojem je na čelu bio Mounier. Personalizam se etablirao 30-ih godina i idućih je desetljeća bio jedan od glavnih pravaca zapadnoeuropske filozofije. Mounierov je personalizam okosnica takozvanih »ne-konformista 30-ih«, grupâ i pojedinaca u međuratnom razdoblju u Francuskoj koji su bili u potrazi za novim rješenjima političke, gospodarske i socijalne krize. ${ }^{1}$ Tražili su »treći put« između socijalizma i kapitalizma, posve različit od liberalizma i fašizma.

Mounier je 1924. godine započeo studij medicine, a potom se posvetio filozofiji, studirajući u Grenobleu, a onda i na Sorbonni. Razočaran sveučilišnom filozofijom počinje izgrađivati vlastiti pristup pod utjecajem Jacquesa Maritaina, Jeana Guittona i Guillaumea Pougeta. Mislioci koji su utjecali na njega još su Gabriel Marcel, Nikolaj Berdjajev i Charles Péguy. Prvo se nadahnjuje Péguyevim likom i djelom, a rezultat toga je djelo Misao Charlesa Péguyja (La pensée de Charles Péguy), koje je 1931. objavio u koautorstvu s Marcelom Péguyom i Georgesom Izardom. Pod utjecajem Péguyja Mounier se usmjerio konkretnom, angažiranom djelovanju, realnim povijesnim iskustvima i napustio je sveučilišnu karijeru smatrajući da ideje treba izreći u akciji i oživotvoriti na političkom i društvom području. Iako je do 1939. godine predavao u gimnaziji u Bruxellesu, to desetljeće je za njega obilježeno osnivanjem časopisa personalističkog pokreta Esprit u Parizu 1932. godine. Časopis uskoro postaje kultni časopis francuske inteligencije, a izlazi i danas.

Godine 1934. objavljuje djelo Personalistička $i$ komunitarna revolucija (Révolution personnaliste et communautaire), izbor ranije objavljenih angažiranih programatskih napisa u kojima zagovara borbu protiv »ustaljenog nereda« kako je shvatio svijet 30-ih godina. Iste godine objavljuje članak, koji izlazi i kao knjižica Od kapitalističkog vlasništva do humanog vlasništva (De la propriété capitaliste à la propriété humaine), u kojem promišlja kapitalističko i njemu suprotno humano vlasništvo. Kao odgovor totalitarizmima iznosi 1936. godine projekt personalističke civilizacije u djelu Manifest $u$ službi personalizma (Manifeste au service du personnalisme), poznatijem pod skraćenim nazivom Personalistički manifest. Zbog kontroverzi u vezi stanja i rata u Španjolskoj piše 1937. godine esej Anarhija i personalizam (Anarchie et personnalisme). Interpretira inspiraciju personalističkog pokreta 1939. godine u eseju Personalizam

\footnotetext{
${ }^{1}$ U ne-konformiste se, pored skupine okupljene oko Mouniera i revije Esprit, navode još skupina Ordre nouveau pokrenuta od strane Alexandrea Marca i grupa Jeune Droite, koja je okupljala intelektualce koji su se nadahnjivali pokretom Action Française. Više u: Jean-Louis LOUBET DEL BAYLE, Les non-conformistes des années 30. Une tentative de renouvellement de la pensée politique française, Paris, Édition du Seuil, 1969.
} 
$i$ kršćanstvo (Personnalisme et christianisme). Iste godine objavljuje studiju o kršćanskoj svijesti i savjesti prema ratu i miru Pacifisti ili belicisti? (Pacifistes ou Bellicistes?). Godine 1942. je proveo nekoliko mjeseci u zatvoru zbog sudjelovanja u pokretu otpora.

Nakon zatvora, u društvenoj izolaciji 1944. godine piše o kršćanstvu kroz dijalog s Nietzscheom pod nazivom Kršćansko suočenje (L'affrontement chrétien). U Pariz se vraća 1945. godine gdje oživljava Esprit, te objavljuje izbor iz djela Charlesa Forbesa Renéa de Montalemberta (1810-1870), francuskog liberalnog katoličkog publicista, pod nazivom Montalembert: Morceaux choisis. Iduće godine objavljuje tri studije o personalizmu u knjizi Uvjetna sloboda (Liberté sous conditions) te čuveno, opsežno djelo Rasprava o karakteru (Traité $d u$ caractère) koje čini personalističku antropologiju i studiju ljudske osobe. Te mu godine izlazi i djelo Uvod u egzistencijalizme (Introduction aux existentialismes) kao reakcija na sartreovsko shvaćanje egzistencijalizma. »Rekapitulaciju« personalizma i samokritiku na personalističku incijativu iznosi u djelu Što je personalizam? (Qu'est-ce que le personnalisme?) 1947. godine. Sljedeće godine, u djelu Budenje crne Afrike (L'éveil de l'Afrique noire) raspravlja pitanje kolonizacije. Godine 1948. objavljuje knjigu Mala bojazan XX. stoljeća (La Petite Peur $d u X X^{e}$ siècle) koja se sastoji od tri predavanja s međunarodnih konferencija.

U idućem djelu Personalizam (Le Personnalisme) 1949. prikazuje personalizam, ne kao neki »stav« u životu, već kao filozofiju koja "precizira strukture osobnog svijeta «. U zapisu Dnevnici iz zatvora (Journaux de prison) iznosi dojmove iz zatvora i štrajka glađu 1942. godine. Jedno od njegovih zadnjih djela je Kršćanski svijet na zalasku (Feu la Chrétienté) iz 1950. godine kojim nastoji duhovno i filozofski utemeljiti otvorenost kršćanstva modernoj civilizaciji i društvu. Njegovi članci, eseji i studije objavljivani su mu i posmrtno, kao npr. politički spisi Teške sigurnosti (Les certitudes difficiles) 1951. godine, studije o Malrauxu, Sartreu, Camusu i Bernanosu Nada beznadnih (Lespoir des désespérés) 1953. godine, njegov vlastiti autoportret Mounier et sa génération. Lettres, carnets et inédits, 1956. godine, a izdana su mu i sabrana djela u četiri sveska CEuvres de Mounier, 1961-1964.

Do 1965. godine ni jedno Mounierovo djelo nije bilo prevedeno na hrvatski ni na srpski jezik. ${ }^{2}$ To je sigurno onemogućavalo širi odjek njegovih ideja na tim jezičnim prostorima, tako da je Mounier ostao u sferi interesa uskog kruga mislilaca koji su vladali francuskim jezikom.

U ovom članku obuhvaćena je recepcija Mouniera do 1965. godine. Tu godinu uzimamo kao prekretnicu jer nastaju »nove marksističke orijentacije« u bivšoj Jugoslaviji, dotada politički, idejno i kulturno zatvorenoj zemlji s dogmatskim marksizmom. Nakon 1965. recepcija Mouniera je značajno sadržajnija,

\footnotetext{
${ }^{2}$ Do sada su objavljena samo dva prijevoda Mounierovih djela: Angažirana vjera (1972.) i Pisma o boli. Pogled na misterij patnje (2006.).
} 
osobito zbog mogućnosti iznošenja i nemarksističke misli u tada oživljenom katoličkom tisku.

Do sredine šezdesetih godina recepciju Mouniera dijelimo na tri razdoblja: prvo na razdoblje do kraja Drugoga svjetskog rata, drugo na poslijeratnu recepciju hrvatske emigracije i treće na poslijeratnu recepciju u Hrvatskoj, odnosno u bivšoj Jugoslaviji. ${ }^{3}$

$\mathrm{U}$ ovom radu pojmovi »osoba« $\mathrm{i} » l i c ̌ n o s t «$ su istoznačnice. Pojam »ličnost« se danas koristi uglavnom u srpskom jeziku, ali je to bio čest predratni izraz i kod hrvatskih mislilaca.

\section{Recepcija do 1945. godine}

U memoarskoj građi sakupljenoj u djelu Hrvatski katolički pokret - moje uspomene Bonifacije Perović, svećenik i valjda najznačajniji hrvatski personalist, personalizmom smatra kretanje u okviru katoličkog socijalnog pokreta onoga vremena. ${ }^{4}$ Osobito se poziva na katoličke laike u Francuskoj okupljene oko časopisa Esprit, Ordre nouveau, Jeune droite i Réaction, koji su željeli goruće probleme zahvatiti u korijenu jer je na djelu bila kriza bitnih vrijednosti i kriza civilizacije. Perović, za razliku od nekih autora, ne smatra da je personalizam nadahnut kršćanstvom, ${ }^{5}$ već da je on sastavni dio katoličkog pokreta. Zapaža i da kršćanski laici okupljeni na političkoj desnici ili ljevici oko navedenih časopisa promiču antikapitalizam, predlažu radikalne zahvate, kritiziraju formalni demokratizam pukog brojenja glasova te traže provedbu »duhovne revolucije« u kojoj bi čovjekova osoba imala prvenstvo. Kao mislioce predvodnike koji su promicali takvu revoluciju Perović ističe Péguya, Bloya, Bernanosa, Mouniera i Maritaina. ${ }^{6}$ Perović je još prije Drugoga svjetskog rata napisao svojevrsni sažetak o tadašnjim katoličkim omladinskim pokretima, među koje svrstava i personalistički:

»Poznati su bili pokreti i njihove revije pod naslovom L'esprit nouveau, L'ordre nouveau, Jugendbewegung i sl. Bila je to spontana reakcija nove zdrave generacije, koja se je htjela osloboditi konvencionalnih laži, pritiska novca i tehnike, a povratiti primat duhu i duhovnoj slobodi. Mnogo toga nam je tada dalo naslućivati da se budi novo pokoljenje koje će prodrmati društvenu ustajalost i probuditi latentne životne duhovne snage na nov život. «"

\footnotetext{
${ }^{3}$ U literaturi, osobito književnoj, ponekad se naznačuje personalizam slovenskih intelektualaca pod vodstvom Edvarda Kocbeka, ali se u ovom članku to ne istražuje. Tzv. Kocbekov »slovenski personalizam« nije imao značajniji utjecaj na hrvatske, kako katoličke, tako ni marksističke mislioce.

${ }^{4}$ Bonifacije PEROVIĆ, Hrvatski katolički pokret. Moje uspomene, Rim, ZIRAL, 1976, 191.

${ }^{5}$ Vidi npr. Franjo ZENKO, Mounierov personalizam suočen s totalitarizmima XX. stoljeća. Kritika predtotalitarnih situacija, Obnovljeni život, 51 (1996) 1-2, 63.

${ }^{6}$ Perović, Hrvatski katolički pokret..., 192-193.

7 Bonifacije PEROVIĆ, Novi čovjek uvjet novog poretka, Luč, 35 (1940) 1, 1-2.
} 
Kao sudionik i jedan od predvodnika hrvatskog katoličkog pokreta Perović se kasnije zapitao zašto ta duhovna revolucija nije donijela rezultata. Podsjeća na to da je nakon Prvoga svjetskog rata stanovit broj mladih hrvatskih katoličkih intelektualaca pohađao sveučilište u Parizu: Milan Ivšić, Ivan Merz, Mario Matulić, Juraj Šćetinec, Đuro Gračanin, Emilio Pallua, Krsto Spalatin i drugi, kao i on sam, te da su te nove ideje i vrenje, kao i duh kritike i suradnje donijeli sa sobom u Hrvatsku, tražeći i provodeći suradnju sa svim pozitivnim snagama u domovini, obarajući se na kapitalizam, formalnu demokraciju i marksizam, a radi izgradnje novog duhovnog čovjeka. ${ }^{8}$ Inače, onodobni katolički mislioci raspravljali su o mnogim personalističkim temama, no u filozofskom smislu nisu uspjeli stvoriti neki zaokružen sustav. Perović se o tome prisjeća:

»Mi smo doduše primali i raspravljali o velikim problemima: demokraciji, humanizmu, slobodi, personalizmu, solidarnosti i sl., ali nam je nedostajao potrebni intelektualni mir i odgovarajući voljni napor da bi ih dublje obradili prema našoj narodnoj i društvenoj stvarnosti. Kada god se to pitanje produbljivanja postavljalo, uvijek se odgovaralo: Najprije moramo izvojštiti narodnu slobodu, pa onda se posvetiti tim dubljim problemima. « ${ }^{9}$

Da su onodobni mislioci bili upućeni u personalistička kretanja potvrđuje i činjenica da se 1937. u izdanju konzorcija »Istina i život«, koju je osnovao Avelin Ćepulić, a uređivao Dušan Žanko, objavljuje u prijevodu Krste Spalatina glasoviti zbornik francuskih personalista Komunizam i kršćani. Za to hrvatsko izdanje predgovor je napisao Daniel-Rops. Taj je zbornik jasno pokazao stav vodećih kršćanskih mislilaca da je marksizam protivnik s kojim nije moguć sporazum jer on politički, filozofski i sociološki stoji u nepomirljivoj opreci s kršćanstvom. Daniel-Rops u zaključnom članku navodi:

»Komunistički pokušaj sjeća nas Luciferovog pokušaja. I on je htio da se oslobodi, i on je htio oživjeti Kraljevstvo. Njegov pad u ponor je sigurno strašan u svojoj veličini: ali on svjedoči za Onoga koji je pobijedio - i svaki od nas mora da ga vječno pobjeđuje. ${ }^{10}$

Budući da je Mounier bio lijeva personalistička »frakcija« ne začuđuje što nije našao svoje mjesto u toj knjizi. Činjenica je da je svećenik i povjesničar Maks Peloza preveo na hrvatski jezik Mounierovo djelo Manifeste au service du personnalisme, ali prijevod nije objavljen. ${ }^{11}$ Peloza je bio lijevo i jugoslavenski orijentiran, ${ }^{12}$ pa je vjerojatno i to pridonijelo stanovitom animozitetu prema Mounieru kod većine hrvatskih katoličkih mislilaca. Očito je da Mounierove

\footnotetext{
${ }_{8}^{8}$ Perović, Hrvatski katolički pokret..., 193-194.

9 Isto, 250.

${ }^{10}$ Daniel ROPS, Sol zemlje, u: Dušan ŽANKO (ur.), Komunizam i kršćani, Zagreb, Konzorcij 'Istina i život', 1937, 247. Pored Ropsa kao autori se u tom zborniku još pojavljuju: Nikolaj Berdjajev, François Mauriac, R. P. Ducattillion, Alexandre Marc i Denis de Rougemont.

${ }^{11}$ Franjo ZENKO, Personalizam i Hrvatska. U povodu 100. godišnjice rođenja Emmanuela Mouniera, Nova prisutnost, 3 (2005) 1, 11.

${ }^{12}$ Perović, Hrvatski katolički pokret..., 229-233.
} 
ideje u tada probuđenom hrvatskom nacionalnom i katoličkom korpusu nisu naišle na plodno tlo. Njima je bila prihvatljivija skupina Ordre nouveau te mislioci kakvi su bili Alexandre Marc i Daniel-Rops. Mouniera spominju samo usputno. Tako je npr. isusovac i izraziti kršćanski personalist Stjepan Tomislav Poglajen u prvoj polovici 30-ih i osobno upoznao Mouniera, ${ }^{13}$ ali ga u svojim mnogobrojnim člancima rijetko spominje. Tek pred kraj Drugog svjetskog rata, za vrijeme boravka u Slovačkoj, gdje je napravio sažetak svojeg rada u toj zemlji, preporučuje katoličkim aktivistima studiranje Mounierovog djela La révolution personnaliste et communautaire. ${ }^{14}$

Franjevac i filozof Hijacint Bošković, prikazujući knjigu Regards Catholiques sur le Monde Dominiquea Auvergnea, navodi da Auvergne u formi razgovora iznosi poglede nekih katoličkih intelektualaca na svijet. U knjizi je zastupljeno 14 pisaca, među kojima su Claudel, Maritain, Mounier, Mauriac i drugi. Kratko prenosi da Mounier govori »o odnosu katolika i tzv. vremenske aktivnosti.$^{15}$ Zaključuje da se $» k o d$ svih očituje temeljna misao naglašavanja čistoće i nadnaravnosti katolicizma i ujedno potrebe da cijeli naš život i sve njegove manifestacije budu prožete tim darom s neba. ${ }^{16}$ Eugen Sladović, jedan od prijeratnih pravnih autoriteta, u članku o osobi i slobodi u nacionalnom socijalizmu, uspoređuje taj pogled s drugim pogledima na svijet, pa i s personalističkim. Podsjeća da su u Francuskoj revolucionari 1789. godine pridavali najveću ideološku vrijednost kategoriji slobode (»liberté«), dok joj novija francuska personalistička struja suprotstavlja osobu (»personne«). Iako u tekstu ne spominje ni jednog personalističkog mislioca, uočljivo je da je dobro upoznat $\mathrm{s}$ njihovim pogledima. Između ostalog, navodi:

»Prema shvaćanju personalista, u zajednici ne opstoji slobodni individuum, nego 〈personne`, čime je doduše priznato virtualno pravo na osobnu slobodu, ali je ono praktički apsorbirano od 〈homme d`une totale responsabilités. To znači, da je spersonne> konkretan čovjek (a ne apstraktan individuum ili atom), koji je usko povezan s određenim životnim prostorom i s određenim socijalnim životnim uvjetima, a čija je harmonija osigurana unutarnjom instancijom (ili svijesti) o njegovu pozivu (vocation) kao čovjeka. Personalisti svode čovjeka na društveno biće, kojemu ne pripada i ne može pripadati naravna neograničena sloboda, koja je ograničena socijalnim mogućnostima.« ${ }^{17}$

Drago Ćepulić, esejist i filozofski pisac, smatra da je Péguya najpodrobnije analizirao Mounier citirajući ga iz knjige La pensée de Charles Péguy:

\footnotetext{
${ }^{13}$ Ivan ŠESTAK, Stjepan Tomislav Poglajen - kršćanski personalist, u: Stjepan Tomislav POGLAJEN, Kršćanski personalizam, Zagreb, Glas koncila, 2010, 9.

${ }^{14}$ Poglajen, Kršćanski personalizam..., 100.

${ }^{15}$ J. Z., Katolički pogled na svijet, Duhovni život, 10 (1938) 4, 250. J. Z. je kratica od Jacek Zumbulov, jedan od pseudonima kojim je Hijacint Bošković potpisivao svoje tekstove.

${ }^{16}$ Isto, 250.

${ }^{17}$ Eugen SLADOVIĆ, Evolucija i devolucija slobode, Hrvatska revija, 12 (1939) 2, 65.
} 
»Filozof će tu naći pojmova koji šepešu, a bogoslov sumnjivih subjekata, državnik će naći neprimjenjivih smjernica. Oni će svi imati pravo sa svog vlastitog stanovišta. Jer od ove misli, koja je uvijek otvorena, ne treba tražiti ni izrađenih pojmova, ni ortodoksije koju naučava, ni zakonodavstva. ${ }^{18}$

I Stjepan Kastropil, književni povjesničar i publicist na kraju članka o Péguyu, Furnieru i Apollinairu donosi kratak popis najboljih dotad objavljenih rasprava i monografija o Péguyu, među kojima je i Mounierovo djelo La pensée de Charles Péguy. ${ }^{19}$

Za vrijeme NDH tekstovi s područja kulture i filozofije usmjereni su na protežiranje njemačke, talijanske, bugarske, rumunjske, slovačke pa čak i finske misli. Mouniera, kao francuskog antifašista i člana pokreta otpora, očito nije bilo preporučljivo spominjati. Ipak, neki autori spominju i oduševljavanje za Mounierova djela za vrijeme rata i poraća kod dijela sveučilišne zagrebačke mladeži. Krsto Cviić, publicist i politički analitičar, navodi sastanke dvadesetak personalistički orijentiranih studenata u prostorijama Katoličke akcije $\mathrm{u}$ Zagrebu do polovice 1943., koja su se nastavila i u poraću u još većem broju jer su im se pridružili i splitski studenti »koji su došli u Zagreb ili da nastave ili da započnu sveučilišne studije . $^{20}$

\section{Recepcija u emigraciji}

Prijeratni hrvatski katolički mislioci, pod vodstvom novinara i književnika Luke Brajnovića te franjevca, filozofa i publicista Hijacinta Eterovića, pokrenuli su 1949. godine u Španjolskoj časopis Osoba $i$ duh, okupljajući hrvatske intelektualce u emigraciji. Naziv, sadržaj i terminologija časopisa, pored čežnje za domovinom, ukazuju na prevladavajući pristup s pozicija kršćanskog personalizma, ali onog kakvog je zastupao Maritain. Spominju i Mouniera, ali ne takvim intenzitetom i odobravanjem. U nepotpisanom članku iz 1949. godine navode da su u to doba personalizam i egzistencijalizam duhovne struje koje najviše obuzimaju duhove u slobodnoj polovici čovječanstva, a da druga polovica iskušava praktičnu primjenu nečovječnog marksizma. Potvrđuju prisutnost Mounierovih misli kod zagrebačke sveučilišne mladeži. ${ }^{21}$ Konstatiraju da je literatura o osobi toliko narasla, da se javljaju glasovi kako bi bilo trebalo stvoriti novu posebnu znanost o čovječjoj osobi: personologiju. Otuda smatraju potrebnim prikazati stajališta različitih filozofskih pravaca o osobi. Za personaliste navode:

\footnotetext{
${ }^{18}$ Drago ĆEPULIĆ, Charles Péguy. O 25. godišnjici njegove herojske smrti, Život, 21 (1940) 1, 20.

${ }^{19}$ Stjepan KASTROPIL, Trojica s mramorne ploče u pariškom panteonu, Savremenik, 28 (1940) $3-4,70$.

${ }^{20}$ Krsto CVIIĆ, Pogovor, u: Ronaldo BAROLDA, Krsto CVIIĆ (pr.), Nesmireni zov - Prijatelji U Pustoj zemlji. Antologija iz olovnih vremena, Zagreb, Dora Krupićeva, 2005, 100.

21 \%**; Oko čovječje osobe, Osoba $i$ duh, 1 (1949) 8, 17.
} 
»Najjači od njih, Emmanuel Mounier, počinje u Francuskoj personalistički pokret 1931. svojom poznatom revijom Esprit, koja još uvijek izlazi. G. 1936. izdava poznati Manifeste au serivce du personnalisme. Ovaj je pisac s krugom svojih suradnika doprinio buđenju interesa za studij čovječje osobe. Njegov bi upliv bio mnogo zaslužniji, kada bi se postavio odlučno na katoličku liniju i kad bi se prestao skrivati iza maglovitih fraza. Temelj njegova personalizma je egzistencijalizam. Sredstvo za njegovo ostvarenje je reforma suvremenog društva na osobnoj bazi. Cilj za koji se oduševljava ovaj pisac i suradnici jest vjera u obraćanje marksista. Odatle nekad, očita, nekad prikrivena suradnja s marksistima. Zato je i njegov jezik do krajnjih granica 'oprezan', da ne povrijedi protivnika.« ${ }^{22}$

Eterović u tekstu o »zatvorenom« humanizmu navodi da je takva vrsta humanizma dosegla svoj vrhunac, te se poziva na Mouniera iz djela Le personnalisme koji

»opisuje ovu krizu u par značajnih poteza: Danas se više ne zna što je čovjek. Budući da on, u našim danima, doživljuje duboke preinake, mnogi misle da uopće nema čovječje naravi. Jedni izražavaju ovo uvjerenje: sve je moguće čovjeku i nalaze neku nadu. Drugi vele: sve je dozvoljeno čovjeku i puštaju sasma uzde. Treći konačno tvrde: sve je dopušteno nad čovjekom. « $^{23}$

U Glasu sv. Antuna književnik Ivo Lendić pišući o franjevačkom redu i hrvatskom narodu iznosi zanimljivo promišljanje:

»Ni Jacques Maritain ni Emmanuel Mounier, začetnici tzv. personalističke filozofije i pokreta, nisu otkrili nešto novo, što nije znao sv. Franjo. Zapravo, ono što personalisti, koji ističu svoje produbljeno proživljavanje kršćanstva i suvremene, posebno socijalne problematike, u okviru kršćanstva, imaju pozitivno; sve se to nalazi u najsavršenijem obliku u franjevačkom personalizmu. ${ }^{24}$

Iznosi i čuđenje »koliko se malo među tim personalistima govori o idealima franjevačkog personalizma - ako s ovim berdjajevskim terminom možemo okrstiti franjevačko shvaćanje ličnosti i teoretski i praktički«. ${ }^{25}$ Ovakvo Lendićevo promišljanje možemo dovesti u vezu sa stavom njegova prijatelja i mentora, Bonifacija Perovića koji personalizmom smatra kretanje u okviru onodobnog katoličkog pokreta. Da su urednici i suradnici Glasa sv. Antuna pratili sva zbivanja u vezi personalizma vidi se i iz vijesti objavljene o likvidaciji i emigraciji dijela slovenskih personalista okupljenih oko Edvarda Kocbeka. Pišu kako je koncem prosinca 1950. godine u Trstu izašao prvi broj revije Stvarnost čiji izdavači pripadaju slovenskoj kršćanskoj skupini koja se pod vodstvom Edvarda Kocbeka priključila tzv. Oslobodilačkoj fronti.

\footnotetext{
${ }^{22}$ Isto, 19.

${ }^{23}$ Hijacint ETEROVIĆ, Zatvoreni i otvoreni humanizam, Osoba i duh, 3 (1951) 1, 7.

${ }^{24}$ Ivo LENDIĆ (Antun Planika), Dolazi čas siromaha: Značenje intimne povezanosti franjevačkog reda i hrvatskog naroda, Glas sv. Antuna, 3 (1949) 10 (1949) 2, 7; citirano prema: Ivo LENDIĆ, Katolicizam i kultura. Eseji, članci i polemike, Zagreb, Glas koncila, 2008, 173.

${ }^{25}$ Isto, 174.
} 
»Nakon završetka rata morali su se pripadnici toga gibanja uvjeriti o svojoj zabludi te zašutjeti ili pak napustiti taj novi svijet, koji su sami sa znatnim žrtvama pomogli graditi, jer su spoznali da to nije novi, pravičniji i slobodniji poredak, nego duhovno uska, policijsko totalitarna komunistička diktatura. ${ }^{26}$

Ocjenjuju da je najzreliji prilog P. Bregara, koji povodom Mounierove smrti razmišlja o francuskom kršćanskom personalizmu, »čiji je najistaknutiji predstavnik bio pokojni Mounier svojom revijom Esprit«. ${ }^{27}$ Informiraju da je preko Esprita personalizam imao jak utjecaj u Sloveniji, posebno na Kocbeka i mislioce kršćansko-socijalnog usmjerenja. Naglašavaju da je Mounier istaknuo primarnu ulogu ljudske osobe, odnosno njezinu vodeću ulogu i veliku odgovornost u društvenom životu, nasuprot mehanizaciji čovjeka u zapadnom kapitalizmu i samovolji nacizma, fašizma i boljševizma. Podsjećaju da je Mounier razloge duhovnog kaosa i propadanja na Zapadu tražio i u mlakosti kršćana te egoizmu i lijenosti uređivanja gorućih socijalnih pitanja. Ističu da je baš zbog toga vjerovao u mogućnost suradnje s komunistima. Prosuđuju da je pri tome ipak sačuvao jasnoću svojega »osnovnoga kršćanskog humanističkog nazora« te se znao »zaštiti od pretijesnoga komunističkog zagrljaja«, ali: »Kad su ga komunisti upoznali, ubrojili su ga među svoje protivnike. ${ }^{28}$ Nakon opisa Mouniera vraćaju se Kocbeku smatrajući da je on skovao neprihvatljivu vrstu dualističkog svjetovnog nazora po kojem za »tvarni svijet i njegove društvene pojave« vrijede pravila dijalektičkog materijalizma kako ga naučava marksizam-lenjinizam, a za čovjekovo duhovno življenje zakoni kršćanstva. Smatraju da su

»komunisti Kocbeku odobravali i pustili ga govoriti tako dugo, dok su njega i njegov krug upotrebljavali da bi posijali zabunu među slovenskim pukom i inteligencijom te stvorili dojam da dio katoličke inteligencije i svećenstva surađuje s Oslobodilačkom frontom odnosno da komunisti imaju najbolju namjeru poštovati vjeru i slobodu. Kad su komunisti osjetili tvrdo tlo pod nogama, potisnuli su još 1943. godine svoje kršćansko-socijalističke saveznike na stranu, te ih Kocbekovim pristankom likvidirali kao skupinu. ${ }^{29}$

\section{Recepcija Mounierova personalizma od 1945. do 1965. godine}

O personalizmu u Hrvatskoj u poratnim godinama akademik Ivan Supičić donosi dragocjeno svjedočanstvo. Navodi da je u neposrednom poraću postojao uzak krug malobrojnih prijatelja, mladih kršćana koji su raspravljali i tajno

\footnotetext{
26 ***;, Slom tzv. kršćanskog progresizma u Jugoslaviji (Kocbekova skupina kršćanskih personalista likvidirana - Pojava revije Stvarnost u Trstu - Kocbekovi suradnici u emigraciji), Glas sv. Antuna, 3 (1951) 8, 3.

${ }^{27}$ Isto, 3.

${ }^{28}$ Isto, 3.

${ }^{29}$ Isto, 3.
} 
se sastajali u Zagrebu i Splitu. Među njima su bila visoko cijenjena osobito tri velika imena personalističke misli: Maritain, Berdjajev i Mounier.

»Za tada mlade hrvatske personaliste bili su to lučonoše duha, a personalizam perspektiva i nada pri svijesti o tome da na visokoj intelektualnoj i duhovnoj razini postoji razrađena suvremena filozofska koncepcija ne samo ljudske osobe i njezina položaja u društvu, nego i društveno-politička koncepcija personalističko-kršćanskog nadahnuća ljudskoga društva i politike.« ${ }^{30}$

Ukazuje da su na tu grupu mladih kršćana imali naročit utjecaj isusovci Ivan Kozelj i Stjepan Poglajen, te prevoditelj Nikola Thaller. Poimenično spominje najistaknutija imena iz tog kruga: Krsto Cviić, Branko Fučić, Roland Jovanović-Barolda, Jure Juras, Miroslav Kurelac, Ivo i Margarita Peraica, braća Dragutin i Živan Sikirić te Radovan i Milan Vidović, Josip Šimetin, Ivan Tomljanović i Franjo Zenko. Ta, brojem mala, ali intelektualnim i duhovnim potencijalom snažna kršćanska jezgra, morala je tada djelovati »podzemno«, bez mogućnosti objavljivanja svojih misli jer je to bilo rezervirano isključivo za marksističke pristalice. Na tu grupu je, prema riječima Krste Cviića, Mounier djelovao nadahnjujući ih »kao utemeljitelj i glavni protagonist personalističke filozofije, čija je središnja ideja bila aktivan angažman za novu civilizaciju, kojoj je u središtu dostojanstvo osobe ${ }^{31}{ }^{31} \mathrm{O}$ članovima te grupe Franjo Zenko navodi:

»Ne samo da su pomno čitali i temeljito studirali tekstove kojima su se, osim određene poezije, nadahnjivali u svom radu, nego su ih na razne načine umnažali i dijelili među pouzdanim prijateljima. To su bili u prvom redu tekstovi modernih filozofa kršćanske orijentacije, posebno onih francuske personalističke struje, kao što su Jacques Maritain (1882-1973) i Emmanuel Mounier $(1905-1950) . \ll^{32}$

Neki od tih članova poslije su dali vrijedne plodove postavši istaknuti hrvatski intelektualci i javni radnici, čak svjetski poznati pregaoci. Potrebno je napomenuti da mladi intelektualci koji se spominju uglavnom nisu pisali o personalizmu jer su se posvetili drugim strukama ili su njihovi tekstovi o Mounieru i personalizmu, kao npr. kod Zenka i Cviića, nastali nakon vremena obuhvaćenog ovom recepcijom. Imajući u vidu samo tu "podzemnu grupu« te djelovanje Stjepana Poglajena i Maksa Peloze, a sagledavajući personalizam samo kroz lijevo orijentiran Mounierov personalizam, Zenko je iznio preusku tezu o personalizmu u Hrvatskoj:

»Personalisti u Hrvatskoj, naime, nikad nisu dosegli onaj stupanj intenzivne javne prisutnosti u hrvatskoj društvenoj zbilji kao što je to uspjelo slovenskoj personalističkoj grupi. No, ni u Hrvatskoj nije nedostajalo pojedinaca koji su se

\footnotetext{
${ }^{30}$ Ivan SUPIČIĆ, Trajna aktualnost kršćanskog personalizma, Nova prisutnost, 9 (2011) 3, 560.

${ }^{31}$ Krsto CVIIĆ, Pogovor, u: Barolda, Cviić (pr.), nav. dj., 93.

${ }^{32}$ Franjo ZENKO, Personalizam i Hrvatska. U povodu 100. godišnjice rođenja Emmanuela Mouniera, Nova prisutnost, 3 (2005) 1, 13.
} 
već od ranih četrdesetih, pa i ranije, intelektualno i duhovno izgrađivali studiranjem Mounierovih radova i čitanjem časopisa Esprit. «3 $^{33}$

Kao opravdanje može se istaknuti da se Zenkovo istraživačko (ne i spisateljsko) razdoblje o Mounieru odvijalo u šezdesetim godinama kada je bio otežan ili onemogućen uvid u nemarksističke, a osobito u protumarksističke tekstove hrvatskih katoličkih personalista. Pri tome se misli na razdoblje tridesetih godina prošlog stoljeća, osobito na djela Milana Ivšića, Jurja Šćetinca i Bonifacija Perovića. ${ }^{34}$

Nakon Drugoga svjetskog rata nastupilo je razdoblje kojeg oslikava književnik Viktor Vida riječima:

»Ovo je doba strasnih paradoksa, lomova i velike zbrke u kojoj homo faber nemoćno prisustvuje rasulu svoje Babilonije, dok homo sapiensa hvata vrtoglavica pred prazninom jasne noći, tjeskobe ništavila. Uprošćenoj je filozofiji ekonomskih fakata sve isuviše transparentno i meni je žao da talent jednog Miroslava Krleže, poslije tragičnih iskustava imperijalizma nacija, rasa i staleža, vidi jedina istinska rješenja u bušenju tunela, u zamjeni opanaka bakandžama, kao da nismo u seljaku sretali staru plemenitost zemlje, a u mnogom gospodinu s lakiranim cipelama osjetili duh prostote. ${ }^{35}$

U Hrvatskoj i na prostorima bivše Jugoslavije nastupilo je doba kada je prestala pluralnost mišljenja, kada je zamrla građanska, kršćanska i svaka druga misao koja nije u skladu s jedinim proklamiranim i ispravnim marksističkim pogledom na svijet. U takvom okruženju i svaki filozofski pravac, osim marksizma, bio je izvrgnut većoj ili manjoj kritici, pa čak i poruzi. O personalizmu su tekstovi izuzetno rijetki, a dolaze iz pera marksističkih mislilaca, uglavnom izvan Hrvatske. Bez obzira na podrijetlo, utjecali su na stav i pristup u svim javnim, kulturnim, znanstvenim i obrazovnim djelatnostima kako na ondašnjoj saveznoj, tako i na republičkim razinama. U članku se iznose i analiziraju takvi stavovi, jer njihov različit pristup Mounieru nagovješćuje napuštanje dogmatskog marksizma i razvijanje različitih marksističkih orijentacija u tom vremenu.

Midhat Šamić, profesor francuskog i latinskog jezika, kasnije ugledni bosanski akademik iznosi stav o personalizmu s pozicija boljševizma. Obrušava se na suvremenu buržoasku filozofiju slijedeći staljinista Ždanova i ruski časopis Boljševik. Sve filozofije izvan marksizma svodi na jedno:

»U savremenoj buržoaskoj filozofiji u Francuskoj, Engleskoj, SAD ima mnoštvo raznih pravaca i škola. Sve te struje nose razne nazive i izme. Međutim, upr-

\footnotetext{
${ }^{33}$ Isto, 11.

${ }^{34}$ Vidi npr. Ivan ČULO, Utjecaj personalizma na hrvatske katoličke socijalne mislioce u 1930ima, Prilozi za istraživanje hrvatske filozofske baštine 39 (2014) 2.

${ }^{35}$ Viktor VIDA, Odjeci Maritaina. Uz 70. godišnjicu francuskog filozofa«, Glas sv. Antuna, 4 (1952) 11, citirano prema: Viktor VIDA, Otključana škrinjica. Eseji, kritike, feljtoni, polemike, Zagreb, Dora Krupićeva, 1997, 226.
} 
kos toj spoljašnoj razlici, u suštini, s gledišta materijalizma, nema bitne razlike među njima. Sve one crpe svoj sadržaj iz idealističkih sistema prošlosti, mahom njemačke filozofije, - misticizma i antagonizma Kanta, subjektivnog idealizma Fihtea, iracionalizma Šopenhauera i Hartmana, fideizma Maha i Avenarijusa, - predstavljaju produženje mahizma i empiriokritcizma i najgore izdanje buržoaske idealističke filozofije - koju je Lenjin davno, na genijalan način, izobličio i raskrinkao. ${ }^{36}$

Kao zajedničko svim tim strujama vidi napade na marksizam i materijalizam, propovijedanje reakcionarnog i dekadentnog idealizma, »odricanje razuma i principa logičnosti da prerasta u klerikalizam i misticizam«, pravdanje buržoaskog poretka i amoralizam. Kod personalizma, prikazujući njihove ideje rezonira:

»Po shvatanju personalista stvarni svijet ne može spoznati nauka, nego religija. Stoga ovi 〈filozofstvujući mračnjaci〉 propovijedaju krstaški rat protiv nauke. « ${ }^{37}$

Za personalističko »uzdizanje ličnosti« smatra da

»nije ništa drugo do najobičnija njihova demagogija, čiji je cilj providan: očuvati buržoasku demokratiju. Za ostvarenje toga cilja personalistima dobro dolazi sve što može tome poslužiti, pa i sam bog, koji je - kako kaže Bihovski - <ideološki ekvivalenat interesa reakcionarnih klasa, koje teže da otklone revolucionarni preobražaj društva'. « ${ }^{38}$

Svoj članak o njemu neprihvatljivoj buržoaskoj filozofiji dovršava riječima:

»Ali najveći otpor na filozofskom, kao i uopšte na ideološkom planu pruža zemlja socijalizma i istinske nauke i naučnih pogleda na svijet - SSSR. Kao što je nekad Lenjin, u svom djelu Materijalizam i empiriokriticizam, zadao težak udarac idealističkoj filozofiji i raskrinkao idealiste svih boja, tako savremeni sovjetski filozofi zadaju sve nove i nove udarce savremenoj buržoaskoj filozofiji. Čitava plejada sjajnih dijalektičara i filozofa kao Bihovski, Transtenberg Dinik, Fak, Svjetlov, među njima i Ždanov i dr., demaskiraju, raskrinkavaju je, pokazuju njeno pravo lice i ukazuju na njen pravi cilj 'da za potrebe tržišta zakrpi i uljepša pljesnivu idealističku robu. To je onaj arsenal koji su sada pustili u saobraćaj filozofski lakeji imperijalizma da bi podržali uplašenog gazdu.' ${ }^{39}$

Šamićev tekst je objavljen 1949. godine, ali je vjerojatno pisan prije sukoba Tita i Staljina, nakon kojega jugoslavenskim ideolozima postaju prihvatljivi svi oni koji su protiv Sovjetskog saveza. Šamić se poslije nastavlja baviti književnošću i drugim područjima znanosti kao marksist, ali bez boljševističkog prizvuka. Stječe ugled u ondašnjoj znanstvenoj zajednici, osobito djelom Kako nastaje naučno djelo.

\footnotetext{
${ }^{36}$ Midhat ŠAMIĆ, Savremena buržoaska filozofija - duhovno oružje imperijalizma, Pregled, 4 (1949) $1,40$.

${ }^{37}$ Isto, 47.

${ }^{38}$ Isto, 49.

${ }^{39}$ Isto, 54.
} 
Iako su Mounieru mnogi zamjerili da nije dovoljno kritički reagirao na ekscese staljinizma u poslijeratnom razdoblju, on je 1948. godine zauzeo pozitivan stav prema Jugoslaviji, namjeravajući je čak i posjetiti. Tada ga je moskovska Pravda napala, a što je kod jugoslavenskih marksista rezultiralo pozitivnom stavom prema Mounieru. To je vidljivo već iz djela Savremena filozofija Zapada Dragana M. Jeremića, srpskog filozofa i književnog kritičara, koje možemo shvatiti kao ondašnji poluslužbeni marksistički stav prema drugim filozofskim kretanjima. Za razliku od Berdjajeva i Maritaina koji su neprihvatljivi, o Mounieru iznosi pozitivan stav. Jeremić personalizam smješta u lijevo krilo francuskog katolicizma i svrstava ga u fideizam. ${ }^{40}$ No, Mouniera izdvaja iz tog kruga i razjašnjava:

»Naša kritika ne sme da bude šablonska i statička, tj. prostim upoređenjem stavova zapadnih filozofa sa marksizmom, i, samo na osnovu toga, utvrđuje naučnu i političku pozitivnost ili negativnost tih stavova, nego dijalektička, što znači da treba uvek voditi računa o smeru razvoja stavova ovih ideoloških pokreta i konkretnim istorijskim uslovima u kojima se ostvaruje taj razvoj. Tako danas treba činiti, izgleda mi, pre svega u razmatranju nekih personalističkih strujanja, koja sve više privode marksizmu grupu katolički odgojenih intelektualaca mlađe generacije. Među ovima na prvom mestu dolaze francuski personalisti okupljeni oko časopisa Esprit i njegova, pre nešto više od dve godine preminula urednika Emaniela Munijea. Na primeru Munijeova personalizma jasno se može videti opasnost od šablonske i statičke kritike. « ${ }^{41}$

Ističe da bi Mouniera šablonski pristup dvadeset godina ranije zauvijek osudio kao reakcionarni fideizam, ali da kasnije i sam Mounier uviđa stalnu potvrdu marksizma na društvenom i planu stvarnog ljudskog oslobođenja. Za prvotni negativan stav tog pokreta prema marksizmu okrivljuje Berdjajeva i njegov članak »Istina i laž komunizma« u prvom broju Esprita, koji je imao presudan utjecaj na personaliste. Smatra da je taj utjecaj vidljiv u Mounierovom djelu Manifest u službi personalizma iz 1936. godine, gdje on smatra da je marksistička koncepcija društva i istorije uperena protiv ličnosti. Ali, Jeremić u tom djelu vidi i prekretnicu jer Mounier uočava da je klevetanje marksizma samo način obrane kapitalizma, a kojeg je i on sam protivnik. Podsjeća da se Mounier »nalazi u taboru prijatelja naše socijalističke zemlje i njenoj borbi protiv porobljivačke politike Informbiroa.$^{42}$ Misli da se Mounierov personalizam ne suprotstavlja marksizmu u epohi socijalističke revolucije, već da suprotnosti nastaju kasnije kad Mounier konačno rješenje nalazi u natprirodnom. Opetovano naglašava »kritički i napredni stav« Mouniera koji

\footnotetext{
${ }^{40}$ Dragan M. JEREMIĆ, Savremena filozofija Zapada, Beograd, Srpsko filozofsko društvo, 1952, 115.

${ }^{41}$ Isto, 170.

${ }^{42}$ Isto, 171.
} 
»očigledno znači jednu pobunu ljudi vaspitanih u katolicizmu protiv filozofije neotomizma, a naročito protiv reakcionarnog delovanja zvanične katoličke crkve. Personalizam je ideja socijalizma ozbiljno prodrla u redove savremene katoličke inteligencije i uzima sve više u maha u Francuskoj kao i van nje. « ${ }^{43}$

Jeremić objavljuje i članak o personalizmu kao filozofiji na raskrnici. Personalizam određuje kao

»filozofski smer koji zastupaju mnogobrojni pojedinci i grupe intelektualaca širom sveta i koji na Zapadu ima aktivnih pristalica više nego ijedan drugi pravac savremene građanske filozofije ${ }^{4}{ }^{4}$

Tvrdi da kritičkom razmatranju personalizma nije posvećeno dostatno pozornosti. Objašnjava korijene personalizma još od antičkog doba, a ukazuje kao značajno njegovo razdoblje u tridesetim godinama prošloga stoljeća. Opisuje da u to vrijeme personalizam prerasta u ideološki pokret, koji ima i izvjesnu političku snagu. U kontekst europskog personalizma kao najznatnije personaliste navodi Maxa Schelera, Nikolaja Berdjajeva, engleske predstavnike Clementa Charlesa Juliana Webba i Hildu Dianu Oakeley, te personalističku grupu oko Mouniera i Esprita. Jeremić svrstava personalizam u pluralistički idealizam i indeterminizam. U smislu teorije vrijednosti shvaća ga kao aksiološki idealizam, a po teoriji spoznaje navodi da je empiristički. U političkim koncepcijama personaliste određuje kao protivnike totalitarizama, hvaleći Mounierovu grupu koja je »vrlo kritička prema kapitalizmu, veoma bliska koncepcijama narodne demokratije, posebno iskustvima Jugoslavije $« .{ }^{45}$ Detaljno analizira personalistički pokret u Francuskoj okupljen oko Mouniera, za kojega navodi

»opštepoznati vođa i glavni ideolog pokreta, bio je uvek na strani naprednih snaga još pre Drugog svetskog rata, a za vreme okupacije učestvovao je u Pokretu otpora, bio zbog toga osuđen i potom živeo i borio se protiv fašizma iz ilegalnosti ${ }^{46}$

Opisuje Mounierov filozofski pogled i komparira ga s marksističkim, koji je po Jeremiću ipak superiorniji. Poglavlje o europskom personalizmu završava riječima:

»Savremeni evropski personalizam je, kao što se vidi, jako razjedinjen i razložen u veliki broj varijanata, iako francuski personalisti, koji imaju najviše autoriteta i najbolje su organizirani, pokušavaju da od personalizma stvore jedinstven ideološki pokret i moralnu, pa i političku snagu međunarodnih razmera, koja će najaktivnije učestvovati u stvaranju sveta u kome će se visoko ceniti individua nerazdvojno povezana sa mnogim idejnim i moralnim recidivima. Ali to ostaje samo želja, a personalizam se nalazi raspet između prošlosti i budućnosti, izme-

\footnotetext{
${ }^{43}$ Isto, 173.

${ }^{44}$ Dragan M. JEREMIĆ, Personalizam ili jedna filozofija na raskrsnici, Savremenik, 1 (1955) 6, 744.

${ }^{45}$ Isto, 747 .

${ }^{46}$ Isto, 749.
} 
đu individualizma i borbe za socijalističko društvo, bez dovoljno odlučnosti da se tog protivrječja oslobodi. ${ }^{47}$

Razvidno je da kod Jeremićevih tekstova o personalizmu primat imaju izvanfilozofijski, prije svega politički pogledi, a koji su onodobni pogledi tada jedine političke partije. Otuda ne začuđuje da se na Jeremića kritički osvrnuo bosanskohercegovački i hrvatski pisac i publicist Predrag Matvejević, dobar poznavatelj francuske misli, ali i kretanja u ondašnjim srpskim filozofskim i književnim krugovima, opisujući ga kao kritičara bez duha, pisca bez stila i filozofa bez vlastitog mišljenja. ${ }^{48}$

Kao Jeremić koji »mudro«, partijsko-politički sagledava personalizam ne postupa beogradska sveučilišna profesorica filozofije Radmila Šajković. Ona s pozicija »tvrde« marksističke misli oštro kritizira personalizam. U uvodu članka u kojem razotkriva antiracionalistički i mistički smisao personalizma navodi da je, uz egzistencijalizam, taj pravac najpoznatiji u suvremenoj francuskoj filozofiji. Objašnjava da se suvremeni personalizam najčešće veže uz Mouniera koji je pokretanjem časopisa Esprit izvršio sistematizaciju personalističke teorije. Misli da personalizam ipak nije filozofski sustav, već da je to struja misli i »tok ideja«:

»Zbog toga je sasvim razumljivo što se među teoretičare personalizma ubrajaju mislioci koji se čak znatno razlikuju u svojim širim koncepcijama, kao na primer: Moris Blondel, Gabriel Marsel, Žak Mariten, Moris Nedonsel, Žan Lakroa, Rober Lenobl, Nikolaj Berdjajev itd. $\ll^{49}$

Određuje da im je svima zajednički izrazito kršćanski duh, te da personalizam, kao i drugi filozofski idealizmi, kartezijansku formulu Cogito, ergo sum uzima za polaznu točku spekulacija, ali

»personalizam je iz kartezijanske formule eliminisao njen najbitniji sadržaj, njen dubok racionalni smisao, prihvatajući je samo formalno i šematski, da bi je na taj način preobratio u potpunu suprotnost. I upravo na toj suprotnosti uzdizaće se celokupna arhitektura personalističke filozofije, skroz prožete jasno izraženim antiracionalističkim i mističkim sadržajem. ${ }^{50}$

Dolazi i do odnosa personalista prema Bogu, ukazuje na mistički karakter personalističkih filozofskih struja koji se vidi i u njihovom rješavanju osnovnog problema, problema ličnosti, a što ocjenjuje:

»Kao što se vidi, personalističko tretiranje problema ličnosti ne predstavlja u razvoju filozofije nikakav doprinos, ma sa kojeg ga stanovišta ocenjivali, jer je

\footnotetext{
${ }^{47}$ Isto, 753.

${ }^{48}$ Iz teksta otvorenog pisma »Pribor za svrgnuće« koje je datirano 7. X. 1984. u: Predrag MATVEJEVIĆ, Otvorena pisma - moralne vježbe, Beograd, Vlastita naklada, 1986, 29.

${ }^{49}$ Radmila ŠAJKOVIĆ, Antiracionalistički i mistički smisao filozofije personalizma, Filozofski pregled, 2 (1954) 4, 6.

${ }^{50}$ Isto, 7 .
} 
sasvim očigledna mistika i to čak, što je veoma karakteristično, mnogo više verska nego filozofska. ${ }^{51}$

Iznosi dalje da antiracionalistički i mistički smisao personalizma dolazi do izražaja i u stavu prema logici i znanosti, te da su personalisti oprečni znanosti, a samim time i marksizmu. Ističe da pri tome i pogrešno poistovjećuju društvenu i intelektualnu stvarnost Sovjetskog Saveza s marksizmom. Ističe i Mouniera kao iznimku od toga. O personalizmu zaključuje:

»Personalizam upadljivo zanemaruje i odbacuje, najveće tekovine savremene filozofije i nauke, bez obzira što ih deklarativno vrlo revnosno prihvata, da bi se sav okrenuo dalekoj prošlosti, hrišćanstvu i Srednjem veku i u njihovoj idejnoj atmosferi pokupio najbitnije elemente za rešavanje ne samo problema ličnosti koji očigledno mistifikuje, nego i svih ostalih problema kojima se bavi.« ${ }^{52}$

Pri tome upozorava i na što treba obratiti pozornost:

»Nikako se ne sme gubiti iz vida da je to filozofija koja se razvija u nedrima hrišćanske religije, neprestano se inspririšući njenim dogmama, mitovima i predanjima, počev od Biblije i najstarijih svetih otaca pa sve do predstavnika srednjovekovne skolastike i mistike. Zato je personalizam daleko od toga da znači i najmanji napredak za filozofsku misao uopšte. « ${ }^{53}$

Šajković potom objavljuje i kritički članak o neotomizmu i Maritainu, čija djela kod nje izazivaju, između ostalog, i »odvratnost «. ${ }^{54}$ Veća filozofska naobrazba od Šamića, razlaz sa staljinizmom i polu-službeno »prihvaćanje« Mouniera razlozi su da ovaj pristup Radmile Šajković sadržajno nije staljinistički, iako duhom to vjerojatno jest.

Slično misli i srpski publicist Žika Radosavljević. Naglašava da

»personalizam, premda sa velikom poentom ukazuje na problem ličnosti, koji je nesumnjivo značajan i aktualan u razvoju savremene filozofske misli, ipak kao takav ne označava nikakav progres u razvoju filozofije, već svojim protiv naučnim i mističkim koncepcijama i stremljenjima znači samo vraćanje u idejni svet Srednjega veka«.55

Za njega je personalizam filozofski pravac »u kapitalističkom društvu na Zapadu koji se, svakako najviše udaljio od racionalnog i naučnog saznanja sveta i čoveka i najintimnije povezao sa mistikom «. ${ }^{56}$ Kritizira personalizam predbacujući mu naročito misticizam, ali kao personaliste navodi samo stavove Gabriela Marcela i Jeana Lacroixa, dok Mouniera ne spominje.

\footnotetext{
${ }^{51}$ Isto, 8.

${ }^{52}$ Isto, 11

${ }^{53}$ Isto, 11 .

${ }^{54}$ Radmila ŠAJKOVIĆ, Katolicizam i obnova skolastike u savremenoj francuskoj filozofiji. Neotomizam Žaka Maritena, Naša stvarnost, 9 (1955) 1, 39.

55 Žika RADOSLAVLJEVIĆ, Personalizam - filozofija ličnosti, Naša stvarnost, 8 (1956) 1-2, 9.

${ }^{56}$ Isto, 9.
} 
Da je personalizam utjecao na umjetnost i književnost, pokazuje već u prvoj polovici 50 -ih slovenski akademik i marksist Boris Ziherl, koji se u raspravi o egzistencijalizmu nadovezuje na Sartrovu podjelu egzistencijalista na kršćanske i ateističke navodeći:

»I krug personalista oko francuskog časopisa Esprit, a naročito njegov osnivač Emanuel Munijer, smatra se kao vrlo blizak 'hrišćanskom' egzistencijalizmu. «" ${ }^{57}$

Povezanost personalizma i književnosti vidljivo je i iz prijevoda članka francuskog publicista i književnog kritičara Pierrea de Boisdeffrea. On navodi:

»Ovu metafizičku kritiku egzistencije početkom 1930-ih godina prihvaća i produbljuje jedan novi naraštaj, u kojem pjesnike i romanopisce smjenjuju filozofi. Pacifističkom humanizmu, što su ga propovijedali Martin du Gard, Duhmel i Romains, generacija Mouniera, Sartrea i Malrauxa suprotstavlja svijest ispunjenu opasnostima. Na mjesto jednog razumnog svijeta, koji se može usavršiti, nastupila je povijest i njene obaveze. Već je daleko svijet, što ga je zastupala mladost Gidea i Mauriaca. Nikoga više ne privlači rezerviranost i bijeg. I sam se Gide, slijedeći nadrealiste, približava komunizmu. Celine u «Voyage au bout de la nuit〉 i u nezaboravnoj 〈Mort à crédit〉 otkriva grozotu jednog univerzuma bez duše, koja uoči Drugog svjetskog rata nadahnjuje Sartreovu «Mučninu〉 i stravične novele «Zida». Drugovi iz ulice Ulm i sa Sorbonne najavljuju «dokazani nered i nastoje zacrtati glavne linije jednog socijalističkog humanizma, marksističkog ili kršćanskog tipa (Arnaud Dandieu, Georges Izard, Daniel Rops pokreću L〉Ordre Nouveau, Emmanuel Mounier osniva Esprit).« ${ }^{58}$

Beogradska sveučilišna profesorica Zagorka Pešić-Golubović je vjerojatno onodobni marksistički mislilac najupućeniji u filozofiju personalizma. Kao filozof, ali i antropolog, već od najranijih radova ne skriva simpatije za Mouniera, kojeg čak u mnogim vidicima postavlja kao suvremenu dopunu i nadogradnju za Marxovo učenje. O Mounierovom personalizmu prvi rad piše 1960. godine. Na početku članka navodi:

»Mada je ponikao iz krize u kojoj se nalazi čovek XX veka i izgrađivao se kao reakcija na ekspanziju totalitarizma, kako kaže sam Munije (Mounier), personalizam ne predstavlja pesmistički odraz teškog stanja u kojem se našao savremeni svet. $\ll^{59}$

Misli da su personalisti postavili osnovne probleme suvremenog čovjeka, te da zahtijevaju njihovo rješavanje. Smatra da Mounier u tome odlazi najdalje, te objašnjava da je njegova filozofija isprva bila vezana za kršćanstvo i iracionalna, ali da postaje realističnija i mnogo više materijalistička, gubeći gotovo potpuno metafizičke crte. Ističući Mounierovu izjavu da je njegova filozofija suprot-

\footnotetext{
${ }^{57}$ Boris ZIHERL, Književnost $i$ društvo, knjiga prva, Sarajevo, Svjetlost, 1958, 203.

${ }^{58}$ Pierre de BOISDEFFRE, Protivurječnosti suvremene francuske književnosti, Riječka revija, 7 (1958) 5, 1958, 332.

${ }^{59}$ Zaga PEŠIĆ-GOLUBOVIĆ, Personalizam Emaniela Munijea, Savremene filozofske teme, 1 (1960) 1, 145.
} 
na idealizmu i da predstavlja afirmaciju materijalizma, povezuje Mouniera i Marxa naglašavajući da će se Mounier

»u mnogo čemu, pogotovo u svojim kasnijim delima, složiti sa Marksom i postavkama istorijskog materijalizma, ali insistira na tome da se mora otići dalje od te osnove da bi se shvatila ljudska ličnost, koja je centralni problem filozofiranja ${ }^{60}$

Smatra da se Mounierova filozofija ne može u potpunosti otrgnuti od kršćanske filozofije, te ga uspoređuje s Maritainom:

»U odnosu na mističku filozofiju Maritena, koja je tipični neotomizam sa personalističkim elementima, filozofija Munijea je daleko racionalnija i naučnija. U tom smislu može se reći da je filozofija Munijea krajnji domet u razvoju personalističke misli.« ${ }^{61}$

Tvrdi da se Mounier zalaže za potpunu interpretaciju čovjeka, te konstatira da on uvodi neke

»nove elemente koji su zanemarivani u marksizmu i da, uzdižući ljudsku ličnost u centar, izgrađuje filozofsku teoriju ličnosti, što kao izgrađena teorija nedostaje marksizmu«.62

Mounierovo određenje ličnosti, te njegovu distinkciju inividue i ličnosti sagledava kao doprinos konstituiranju suvremene teorije ličnosti. Doprinos vidi i u rješavanju problema odnosa ličnosti i društva, gdje objašnjava da je Mounierov personalizam suprotan individualizmu, ali i »takozvanom kolektivizmu«. Često uspoređuje egzistencijalizam i personalizam dajući prednost Mounieru. Objašnjava i Mounierovo neslaganje s egzistencijalizmom u objašnjenju slobode i odnosa determinizma i indeterminizma, te dolazi do sličnosti personalističkog i marksističkog shvaćanja. U drugom dijelu članka piše o Mounierovom nastojanju da nađe rješenje tragične sudbine suvremenog čovjeka. Pri tome naglašava njegov stav da je kapitalizam neprijatelj ličnosti, te da je marksizam najjača reakcija protiv dekadencije suvremenog društva. Razjašnjava i Mounierovo shvaćanje razlike marksizma i personalizma. Intonaciju stavlja na Mounierov stav da personalizam može nadići neke marksističke jednostranosti te se slaže da bi personalizam mogao biti dopuna marksističkoj filozofiji:

»Kao takva, personalistička filozofija mogla bi biti u izvesnom smislu dopuna marksističke filozofije, u kojoj je mnogo detaljnije razrađena ‘spoljna〉 društvena strana i karakteristika ličnosti. ${ }^{63}$

Izvodi zaključak o odnosu personalizma i marksizma:

\footnotetext{
${ }^{60}$ Isto, 146.

${ }^{61}$ Isto, 147.

${ }^{62}$ Isto, 147.

${ }^{63}$ Isto, 156.
} 
»Povezanost personalizma sa marksizmom najviše je izražena u Munijeovoj filozofiji. Smatramo da je pogrešno tumačenje, na koje se često nailazi, da je personalizam antiteza i reakcija na marksizam. Iz onoga što smo izložili vidi se da personalizam i marksizam u najbitnijim tačkama ne predstavljaju suprotnosti, i kao što kaže sam Munije, on prihvata sve pozitivne tekovine marksizma. « ${ }^{64}$

U prilog tom zaključku poziva se i na stav personaliste Johna Bournea Coatesa o tome da se većina Mounierovih shvaćanja temelji na marksističkim tradicijama. Ponavlja da postoje i značajne razlike između personalizma i marksizma, te da je osobito kršćanska metafizika personalizma nespojiva sa marksizmom. Misli da ti elementi postoje više $» k a o$ okvir Munijeove filozofije nego kao imanentna suština, koja bi mu smetala da vidi realni svet i čoveka u njemu« ${ }^{65}$ Navodi i slabosti Mounierove filozofije ističući da je njegova teorija ličnosti pretežno filozofske orijentacije koja mu onemogućuje sagledavanje u potpunosti konkretnog čovjeka određenog društva. Misli da Mounier nije u potpunosti shvatio ni da je oslobođenje društva uvjet slobode ličnosti, kao ni pravu vrijednost rada. Na kraju zaključuje:

»Iz svega proizlazi da je personalistička filozofija Emaniela Munijea važno poglavlje u razvoju filozofske misli, a posebno značajan doprinos savremenoj teoriji ličnosti, usprkos slabostima kojima je opterećena.« ${ }^{66}$

Da je došlo do svojevrsne slobode na izdavačkom planu početkom šezdesetih u bivšoj državi vidljivo je iz pojave prijevoda i stranih djela u kojima se različiti mislioci, pa i idejni protivnici marksizma, spominju u realnijem kontekstu. Kao takvo djelo može se navesti djelo francuskog pisca Gaëtana Picona Panorama savremenih ideja, koje na početku šezdesetih objavljuje beogradska izdavačka kuća Kosmos i koja je bila prvo strano djelo koje je priručnički pružalo uvid u tadašnja suvremena misaona kretanja. Na više mjesta se spominje Mounier, iako sam autor navodi da žali što u prikazu filozofskih ideja nije našao mjesto »hrišćanski personalizam Munijea «. ${ }^{67}$ Mouniera i Marcela obrađuje u poglavlju o suvremenom humanizmu kao predstavnike "personalističkog humanizma«. Za Mouniera navodi da nije pridonio personalističkom humanizmu filozofskim produbljivanjem, već time što mu je dao oblik borbene doktrine. A ta doktrina ima svojstva

»jedne etike dovoljno konkretne da nosi sa sobom neposrednu primenu (naročito na društvenom planu), dovoljno opšte i jednostavne da bi za sebe privezala priličan broj duhova koji se inače po drugim tačkama ne slažu«. ${ }^{68}$

\footnotetext{
${ }^{64}$ Isto, 157.

${ }^{65}$ Isto, 158.

${ }^{66}$ Isto, 163.

${ }^{67}$ Gaëtan PICON, Panorama savremenih ideja, Beograd, Kosmos,1960, 39.

${ }^{68}$ Isto, 593.
} 
Picon smatra da je personalizam, zahvaljujući Mounieru, jedna škola i pokret, a časopis Esprit važan činilac suvremene ideološke atmosfere. Za ilustraciju se na nekoliko stranica donose ulomci iz Mounierovog djela Što je personalizam?69

U časopisu Naše teme objavljen je prijevod dijela knjige Francesca Valentinija La filosofia francese contemporanea. U tom tekstu Valentini spominje i Mouniera govoreći o Camusovim kršćanskim motivima:

»Radi se o kršćanskim motivima, o motivima <ateističkog〉 kršćanstva, no koje je na svoj način suvislo i nije daleko u onom što mu je bitno od kršćanstva «laičkih〉 katolika kao što su Maritain ili Mounier. Jer najvažniji politički nišan, zapravo jedini u toj fazi, jest historicizam, a na političkom planu komunizam. « $^{70}$

U tom časopisu članak objavljuje i Franjo Zenko, kasnije pobornik personalizma, prikazujući članke objavljene u Espritu 1960. godine. Ovaj rad možemo označiti kao početak Zenkovog bavljenja Mounierovim personalizmom. Članak započinje općim podacima o časopisu Esprit:

»Esprit je eminentni francuski personalistički mjesečnik sa 30-godišnjom dosta utjecajnom idejnom tradicijom u francuskoj javnosti. Osnivač mu je Emmanuel Mounier, filozof-publicist, idejni začetnik i vođa francuskog personalizma. « ${ }^{71}$

Smatra da se časopis može okarakterizirati kao »duhovni dnevnik« personalističkog pokreta u Francuskoj 30-ih godina. Kao uvod za objašnjenje personalističke struje Zenko koristi članak iz Esprita posvećen 10-godišnjici smrti Mouniera »Prisutnost Emmanuela Mouniera« autora Jacquesa Natansona. Prenosi neke Natansonove teze i stavove o personalizmu. Između ostalog:

»Sav napor personalizma oko izgrađivanja svog vlastitog idejnog i praktičnog stava odvija se kroz 〈personalističku kritiku marksizma i egzistencijalizma.. $^{72}$

Ta tvrdnja potkrjepljuje se Mounierovim stavom da otvoreni marksizam ne može biti odviše udaljen od personalističkog realizma. Navodeći dalje relacije personalizma i marksizma, Zenko navodi, iako nije posve razvidno je li to njegovo mišljenje ili Natansonovo:

"Stoga se općenito može kazati da je personalizam u stvari eminentno idejni stav rođen u jednoj konkretnoj društvenoj situaciji i nosi mnoge njene nedoumice, predrasude, pitanja itd. U svakom slučaju radi se o stavu bez definirane, konstantne i čvrste političke prodornosti u današnjem «ustaljenom neredu〉 zapadnog građanskog svijeta, o stavu bez organiziranog revolucioniranja konkretne klasne društvene strukture. «73

\footnotetext{
${ }^{69}$ Isto, 594-596.

${ }^{70}$ Francesco VALENTINI, Od nihilizma do moralizma. Albert Camus, Naše teme, 5 (1961) 11, 1667.

${ }^{71}$ Franjo ZENKO, Personalistički krug, Naše teme. 5 (1961) 4, 612.

${ }^{72}$ Isto, 614.

${ }^{73}$ Isto, 614.
} 
U daljnjem tekstu nastavlja ukratko prikazivati sadržaj časopisa do kraja 1960. godine.

Mario Festini, talijanist i sveučilišni profesor u recenziji knjige Kriza savjesti talijanskog novinara i političara Ignazija Silonea smatra da se Siloneova etičkoegzistencijalistička tendencija umjetnosti nadovezuje na filozofiju Emmanuela Mouniera. Pojašnjava da »taj francuski filozof, koji u biti stoji na pozicijama katoličkog egzistencijalizma, ima i mnogo dodirnih tačaka s marksističkom etikom «. ${ }^{74}$ Navodi neke Mounierove misli i ističe da su imale osjetljiv utjecaj na suvremenu talijansku filozofiju i književnost.

Za razliku od beogradskog, zagrebački sveučilišni filozofski krug u desetak godina od Drugog svjetskog rata, uglavnom ne spominje i ne raspravlja o suvremenim filozofskim kretanjima. ${ }^{75}$ Donekle je izuzetak Rudi Supek koji piše o egzistencijalizmu. Ovdje treba istaknuti da je bilo iznošenja misli o potrebi osuvremenjivanja marksizma, ali ne u kontekstu uvida u druge filozofske pravce. U tom krugu, pri Filozofskom fakultetu u Zagrebu počinje izlaziti časopis Praxis 1964. godine koji želi osloboditi filozofiju od podložnosti politici i partiji, istraživati »istinitog i pravog Marxa«, ali ne »da se kod njega ostane, nego polazeći od njega da se ide dalje ${ }^{76}{ }^{7}$

Mouniera spominje filozof i sveučilišni profesor Danko Grlić u raspravi o apstraktnom i realnom humanizmu:

»Često i nismo svjesni koliko je tehnika zloupotrebljavana protiv čovjeka i kako bitno pridonosi dehumanizaciji našeg svijeta, upravo onda i samo onda kad se stavlja iznad čovjeka, kad njega samog želi učiniti strojem, ili, štaviše, slugom stroja, dakle manje vrijednim od njegove vlastite tvorbe. U tom smislu mogli bismo se složiti s jednom lucidnom tezom Emmanuela Mouniera, da je čovjek takvog tehničkog komfora 〈domaća životinja svih predmeta svoga komfora〉: «77

Sociolog, publicist i sveučilišni profesor Josip Biškup objavljuje članak »Personalizam - etika izgubljenog čovjeka«. S obzirom na to da Biškup nije iz kruga eminentnih marksističkih filozofa, na njegov osebujan interes od pjesništva i filozofije do šumarstva i kadrova u drvnoj industriji, kao i na regionalnu publikaciju objavljivanja, članak možemo shvatiti dvojako. Kao marginalni, »blagi« marksistički pogled na personalizam ili kao na svojevrsni intelektualni pokušaj obzirnog ukazivanja da postoji filozofija i izvan marksizma. Na početku članka Biškup smatra da nije na odmet da se ondašnja javnost upozna s tim filozofskim pravcem:

\footnotetext{
${ }^{74}$ Mario FESTINI, »Kriza savjesti« Ignazija Silonea, Zadarska revija, 11 (1962) 1, 33.

${ }^{75}$ Vidi npr. poglavlje »Popis radova nastavnika Filozofskog fakulteta od oslobođenja do kraja 1953.«, u: Antun BARAC i dr. (ur.), Zbornik radova, knjiga II, Zagreb, Sveučilište u Zagrebu Filozofski fakultet, 1954.

${ }^{76}$ Marko MATIĆ, Kršćanstvo i marksizam šezdesetih godina, Obnovljeni život, 34 (1979) 1, 29.

${ }^{77}$ Danko GRLIĆ, O apstraktnom i realnom humanizmu, u: Branko BOŠNJAK i dr. (ur.), Humanizam i socijalizam: zbornik radova, prva knjiga, Zagreb, Naprijed, 1963, 140.
} 
»Suvremena filozofija Zapada bogata je mnogim pravcima, a svi oni imaju zajedničko to da zatvaraju oči pred istinom i žele je pronaći tamo gdje je nema (...) Budući da je personalizam eklekticizam koji bez ustručavanja prihvaća mnoge postavke marksizma i želi da se postavi s onu stranu materijalizma i idealizma, i budući da je personalizam pokušaj modernog humanizma, smatram da neće biti na odmet da se i naša javnost upozna s ovim filozofskim pravcem. ${ }^{78}$

Kao najznačajnijeg i najaktivnijeg suvremenog personalista vidi Mouniera. Navodi neka njegova djela uz opasku da on »kao i neki drugi personalisti, koketira s egzistencijalizmom, a blizak mu je i kristijanizam $\ll .{ }^{79}$ Da ne bude sumnje s koje pozicije Biškup piše, naglašava:

»Ni kod Mouniera, kao ni kod ostalih personalista, nema odlučnog revolucionarnog stava, iako oni pretendiraju da personalizam bude revolucionaran. Progresivne misli, ukoliko i postoje, samo su trenutna iluminacija, gotovo uvijek su natovarene nepotrebnim balastom, opterećene metafizikom i religijom. $\aleph^{80}$

Spominje da je personalizam brzo našao sljedbenike i u drugim kapitalističkim zemljama, te je i u njima uloga personalizma bila negativna, jer je otupljivao »oštricu revolucionarnosti i uljuljkivao proletarijat u iluzijama ${ }^{81}{ }^{81}$ Biškup dalje u članku iznosi stavove personalizma o depersonalizaciji, ličnosti, odnosu čovjeka prema drugom čovjeku, prirodi i tehnici, razlici između ličnosti i individuuma, duhovnosti, ljubavi i drugim mislima svojstvenima personalistima, pozivajući se ponekad i na Mouniera. Iako je razvidan Biškupov ambivalentan stav o personalizmu, naglašava da se on ipak ne može mjeriti s marksizmom:

"Zaista, personalizam bi bio revolucionaran da se s ovim svojim idejama pojavio prije dva stoljeća. Danas, uz tako snažnu afirmaciju marksizma, on može biti samo reakcionaran. Možda manje reakcionaran nego druge filozofije na Zapadu, ali ipak reakcionaran. $^{82}$

Smatra da je personalizam »najnapredniji filozofski pravac što ga je stvorilo kapitalističko društvo « ${ }^{83}$ ali da ne postavlja i ne daje odgovor na pitanje što je s proletarijatom i revolucijom. Članak završava:

»Na kraju treba reći da je personalizam filozofija, koja prihvaća čitav niz već poznatih istina pa je prema tome najobičniji eklekticizam. Ona je samo još jedan dokaz više da se jedno društvo našlo u situaciji kojoj ne nalazi rješenje. Personalizam je ideološka kapitulacija kapitalizma! ${ }^{84}$

\footnotetext{
${ }^{78}$ Josip BIŠKUP, Personalizam - etika izgubljenog čovjeka, Revija - časopis za književnost, kulturu i društvena pitanja, 3 (1963) 3, 122.

${ }^{79}$ Isto, 123.

${ }^{80}$ Isto, 123.

${ }^{81}$ Isto, 124.

${ }^{82}$ Isto, 127-128.

${ }^{83}$ Isto, 128.

${ }^{84}$ Isto, 130.
} 
Iako je bio poslijeratni jugoslavenski ambasador u Francuskoj Marko Ristić, književnik i predvodnik srpskog nadrealizma, nije zastupao onodobni ortodoksni marksizam, već se iz njegovih tekstova vidi sklonost ondašnjoj aktualnoj francuskoj kulturi i filozofiji, a osobito »angažiranoj« književnosti, pojmu uz koji se veže i Mounier. U dnevničkim zapisima spominje Mouniera govoreći o događanjima u Parizu krajem 40-ih godina prošlog stoljeća kada je u Pariz stigao Garry Davis, "prvi građanin svijeta«, za vrijeme rata američki zrakoplovac koji se odrekao američkog državljanstva zastupajući stav da je pripadništvo naciji, ma koja ona bila, nespojivo s totalnom odanošću čitavom čovječanstvu. Ristić piše:

»Došao je u Pariz i tu, kad mu je 17-og septembra istekla dozvola boravka, potražio je azil na teritoriji Ujedinjenih nacija, to jest pod tremom palate Chaillot. Ali ga je odatle, posle njegovog višegodišnjeg otpora, policija naravno oterala. Oko Garry Davisa obrazovan je jedan 'Savet solidarnosti' u komu se, između ostalih, našli i Georges Altmann, Claude Aveline, Claude Bourdet, André Breton, Albert Camus, profesor Pierre Girard, Emmanuel Mounier, Jean Paulhan, Magdeleine (Magdeleine Marx), abbé Pierre, Raymond Quenneau, Robert Sarrazac, Vercors, Richard Wright. Na dan kad je Garry Davis pokušao da svojim internacionalističkim apelom uzbudi hladna srca ounovskih delegata, u sali su se nalazili neki od Davisovih pristalica i simpatizera: Paulhan, Mounier, Louis Martin-Chauffier, Camus, Breton, Benjamin Péret i još nekoliko nadrealista.« ${ }^{85}$

\section{Zaključna promišljanja}

Do kraja Drugog svjetskog rata katolički i drugi mislioci spominju Mouniera samo usputno, a kasnije i hrvatski emigrantski mislioci zadržavaju prema njemu rezerviran stav. U poslijeratnom razdoblju gotovo dva desetljeća egzistirala je samo marksistička literatura, a o personalizmu su pisali uglavnom autori izvan Hrvatske. No, iz toga nikako ne možemo površno zaključiti da je recepcija Mounierove filozofije ljudske osobe i društva imala u središtu komparaciju i konfrontaciju s marksizmom, niti da je se glavni odjek njegovih ideja zbivao izvan Hrvatske. U bivšoj državi nastupila je dominacija marksističkog pogleda na svijet koji je gotovo pola stoljeća bio službeni i jedini prihvatljivi smjer promišljanja. Drugi filozofski pravci sagledavani su uglavnom kao veća ili manja odstupanja od marksizma, te su se spominjali usputno ili na marginama marksističkih promišljanja. S obzirom na to da je u to doba personalizam, uz egzistencijalizam, bio najznačajniji europski filozofski pravac, njegova gotovo potpuna odsutnost u našim krajevima znači nedostatak jedne važne karike europske filozofije i misli 20. stoljeća. Razdoblje kraja 50-ih u marksizmu obi-

\footnotetext{
${ }^{85}$ Marko RISTIĆ, 12 CC (Pariz 8. 11. - 12. 12. 1962.) Naknadni dnevnik (nastavak IX), Forum, 3
} (1964) 7-8, 101. 
lježava nastanak tzv. »nove ljevice« koja dovodi u pitanje ortodoksiju, koncipira »reformski socijalizam«, napušta parolu baze i nadgradnje, te nudi suptilniju kulturu kao sferu u kojoj ljudi aktivnije ostvaruju svoj identitet. ${ }^{86} \mathrm{Za}$ reviziju marksizma u istočnoj Europi već početkom 60-ih zalažu se Leszek Kołakowski i Adam Schaff, a kod nas kao prijelomni trenutak se označava početak izlaženja časopisa Praxis 1964. godine. Istovremeno dolazi i do promjene pristupa Katoličke crkve, osobito u smislu dijaloga, koji kulminira Drugim vatikanskim koncilom (1962.-1965.). U nas je to značilo i oživljavanje katoličkog tiska, te uspostavljanje početnog dijaloga katoličkih i marksističkih mislilaca.

Do toga trenutka recepcija prema nemarksističkim, a osobito katoličkim misliocima, a osobito prema personalizmu, bila je izrazito negativna: od boljševičkih napada do svrstavanja u nazadnu antiracionalističku misao koja vodi u Srednji vijek. Iznimka postoji prema Mounieru, kojeg poslijeratni marksisti nakon raskola Tita i Staljina 1948. godine doživljavaju pozitivno zbog njegove javno izražene sklonosti prema bivšoj Jugoslaviji. Pri tome je uočljivo pretjerivanje o Mounierovoj sklonosti marksizmu, komunizmu i socijalizmu, čak uz svrstavanje $u$ »tabor prijatelja naše socijalističke zemlje«. Prenaglašavala se specifičnost Mouniera u odnosu na druge predstavnike personalizma, kao što su npr. Berdjajev i Maritain, o kojima je vladala izrazito negativna recepcija. To je svojevrsni filozofsko-povijesni raritet, osobito kada se ima na umu da je Mounier bio izraziti katolički mislilac. Otuda na Mouniera možemo gledati i kao na prethodnicu tzv. približavanja kršćanstva i marksizma 60-ih godina prošlog stoljeća.

Moguće je pozitivan marksistički stav prema Mounieru tumačiti i kao politički pragmatizam onodobnih jugoslavenskih ideologa i političara koji su svojim »službenim filozofima« uvjetovali takav pristup. Indicija za takvo tumačenje je i činjenica da je stav prema onodobnim suvremenim filozofskim kretanjima i dvadesetak godina nakon Drugoga svjetskog rata i zemljopisno dolazio iz centra u kojem je bila i politička moć.

\footnotetext{
${ }^{86}$ Charles TAYLOR, Prizivanje građanskog društva, Beograd, Beogradski krug, 2000, 4.
} 


\section{Ivan Čulo*}

The Reception of Emmanuel Mounier in Croatia and the former Yugoslavia until 1965

\section{Summary}

The work reviews and analyzes the reception of the French Catholic philosopher and thinker, originator of personalistic movement, Emmanuel Mounier (1905-1950) in Croatia and the former Yugoslavia until 1965.

It investigates the articles on Mounier, his own works as well as his influence on personalistic endeavours in the region. First brief echoes of his thought on Catholic and pronounced thinkers in Croatia can be found as early as in 1930-ies, however, without any relevant positive or negative criticism. Namely, Mounier's tendency towards Marxism and socialism was not acceptable for them. Croatian emigrants adhered to such reserved sentiments towards Mounier. After the Second World War the only acceptable standpoint was Marxist and personalism, being considered as a "bourgeois philosophy", was denied. The only exception was Mounier, to whom the post-war Marxists have an ambivalent attitude and after the break of Tito and Stalin in 1948, even a positive one. This is a philosophical-historical rarity, taking into account that Mounier was an apparent Catholic thinker. Hence reception of Mounier can be considered as a vanguard of the so-called convergence of Christianity and Marxism in 1960-ies but also as a political pragmatism of then Yugoslav official ideology.

Key words: Emmanuel Mounier, personalism, reception in Croatia and ex-Yugoslavia, catholic thinkers, marxists.

(na engl. prev. Mirela Budojević)

\footnotetext{
* Ivan Čulo, MA Law, BA Philosophy, Doctoral candidate at Faculty of Philosophy and Religious Studies, University of Zagreb; Address: Institut Fontes Sapientiae, Kušlanova 59, HR-10000 Zagreb, Croatia; E-mail: institutfs@gmail.com.
} 